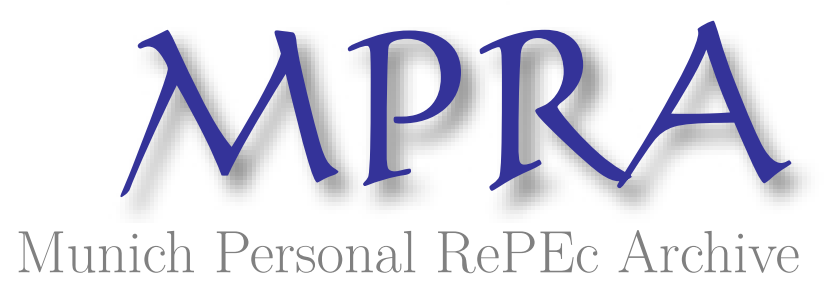

\title{
David and Goliath: small banks in an era of consolidation. Evidence from Italy
}

Bongini, Paola and Di Battista, Maria Luisa and Zavarrone, Emma

University of Milan-Bicocca; Catholic University of Piacenza

2006

Online at https://mpra.ub.uni-muenchen.de/4841/

MPRA Paper No. 4841, posted 12 Sep 2007 UTC 


\title{
David and Goliath: small banks in an era of consolidation. Evidence from Italy
}

by

\author{
Paola Bongini ${ }^{\mathrm{n}}$, Maria Luisa Di Battista ${ }^{\square}$ and Emma Zavarrone ${ }^{\mathrm{m}}$
}

JEL classification numbers: $G 21, G 34$

Keywords: Small banks, relationship lending, consolidation

昌 Università degli Studi di Milano-Bicocca, Piazza dell'Ateneo Nuovo 1, 20126 Milano, Italy; email: paola.bongini@unimib.it tel: +3902 64486512; fax +3902 64483142; emma.zavarrone@unimib.it; Cattolica del S.Cuore di Piacenza, via Emilia Parmense 84, 29100 Piacenza, Italy, email: marialuisa.dibattista@unicatt.it

Corresponding author: Paola Bongini.

We thank Mario Anolli, Laura Nieri and Paola Tornaghi for their helpful comments. The authors are solely responsible for the contents of the paper. A special thank goes to Olivier De Jonghe for his valuable comments as discussant and to participants of the European Banking Symposium at Bocconi University (Milan, $5^{\text {th }}$ and $6^{\text {th }}$ June 2006) and to participants of the European Financial Management Association Annual Meeting (Universitad Complutense, Madrid, $28^{\text {th }}$ June- 3 July 2006). 


\section{Abstract}

Consolidation in the banking industry has caused concern about the survival of small banks. However, empirical evidence shows that often small banks are performing better than larger banks in terms of loan growth and profitability. This paper addresses the main question of "how David can be successful in a Goliath's world" analysing two broad sets of issues, tested on a sample of Italian small banks. We first address the question of whether peculiarities of small banks, e.g their ability to lever on relationship lending, are good explanatory variables of their loan growth. Second, we investigate the relationship between loan growth and profitability and credit risk to point out which small banks can continue to be a viable competitor of larger bank. 


\section{Introduction}

Several trends in the financial industry have threatened the survival of small banks in recent years.

Economies of scale in the production of financial services, sophisticated (and costly) risk management techniques, customers' preference for one-stop-shopping, and the related bank's need to diversify into different lines of business (and sources of revenues), the consolidation process in the bank sector,......all are evidence of an economic arena where only large banks are seemingly fit to operate and survive. In a world made for Goliath, David might be at such a disadvantage that he will no longer survive.

Despite these challenges, empirical evidence from the US and Italy shows that small banks not only survive, but also have been growing more rapidly than their larger competitors over the recent period, conquering new loan and deposit market shares at the expenses of large banks, while maintaining high profitability standards.

A recent study of the drivers of the increased importance of Italian small banks suggests that their loan growth is to be mainly attributed to organizational diseconomies at large banks (Bonaccorsi di Patti et al.,2005). Indeed, large Italian banks are facing restructuring and reorganizing problems after their numerous M\&A operations and the introduction of more advanced risk management techniques, stimulated by the new capital adequacy regulatory rules (Basle 2). As a consequence, Italian small banks might be successful because large banks are retreating, making room to them. One possible conclusion is that the better performance of small banks appears to be a transitory phenomenon. As soon as large banks are back in action, small banks will lose their advantage.

However, in our judgement, this conclusion is drawn without deeply exploring the wide literature on peculiarities of small local banks. Our paper levers on this literature and addresses the 
main question of "how David can be successful in Goliath's world". Two broad sets of issues will be investigated.

The first question is whether peculiarities of small banks are good explanatory variables of their loan growth. In particular, we posit that, in terms of loan growth, best performer in the small banking group are those banks who are good at ripening the hypothesized small bank advantages, such as their ability to process and use soft-information (Banerjee et al., 1994; Besley and Coate, 1995; Stiglitz, 1990). Differently from previous literature which considers small banks as a unique, homogeneous group, or simply focuses on the sub-group of credit cooperatives, our study considers a sample of banks comprising three different types of small banks - cooperatives, small banks belonging to groups, independent small banks - and tries to highlight the importance of relationship lending for each type of bank organization ${ }^{1}$.

Second, the relationship between loan growth and profitability and credit risk is analysed. In fact, a sizeable loan growth could be pursued accepting a higher risk profile and a reduction in profitability, with negative repercussions on their long run stability. If this is the case, the small banking group is likely to face soundness problems in the near future. Our main contribution consists in shedding light on what constitutes a fit shape for a small bank in an era of consolidation. Combining our analysis with the results achieved by Bonaccorsi di Patti et al. (2005), we can construct a strategic matrix to identify which small banks are likely to continue to be viable competitors of larger banks, e.g. those able to combine structural advantages with a favourable situation in which large banks face difficulties in maintaining their loan market share.

The rest of the paper is organized as follows: Section 2 provides the motivation of research and reviews the relevant literature; Section 3 discusses our methodology and data; Section 4 presents our results and Section 5 our conclusions.

\footnotetext{
${ }^{1}$ This is particularly important since, in many countries, there is a trend which sees large banking groups re-discovering the importance of being close to their territory - at least for their retail banking activities - and tend to re-organize their businesses in different entities, comprising small local players.
} 


\section{Motivation of research and review of the empirical literature}

In recent years, in most developed countries, the survival of small banks has been threatened by various challenges: advances in IT, economies of scale in the production of new and more sophisticated financial instruments, innovations in bank production processes, e.g. the introduction of innovative (yet costly) risk management techniques, customers' preference for one-stopshopping and the bank's need to diversify into different lines of business (and sources of revenues). Last, but not least, worldwide the banking sector has undergone a substantial consolidation. These trends appear to favour large banks at the expense of small banking institutions. All in all, in a world designed for Goliath, David might be at a disadvantage and find it particularly difficult to survive. As a matter of fact, the number of small banks has shrunk in most countries. This holds true for all types of banks, as a natural consequence of the process of consolidation which indistinguishably concerned all banking institutions. However, since small banks are a primary source of financing for small firms, the decline in the number of small banks has raised the concern that the access of small businesses to credit may be restricted. Therefore a fair amount of (mainly empirical) literature has been produced on the effect of bank consolidation on small business lending. In this specific area of study, an interest is cast on the potential differences in the way large and small banks approach small businesses. However, the real focus of these studies is on the availability of credit for small businesses after M\&As (Petersen and Rajan, 1995; Berger et al., 1998; Goldberg and White, 1998; Peek and Rosengren, 1998; DeYoung et al., 1999; Boot, 2000; Ongena and Smith, 2000; Bonaccorsi di Patti and Gobbi, 2001; Berger and Udell, 2002; Focarelli, Panetta and Salleo, 2002; Sapienza, 2002; Avery and Samolyk, 2004; Gobbi and Lotti, 2004). Indeed, to the best of our knowledge, the issue of survival (and the future) of small banks has been directly investigated by few studies. 
For the U.S. banking system, Basset and Brady (2002) document that, during the period 1985-2001, small bank assets have grown at rates exceeding their large bank competitors while maintaining their historically high levels of profitability, even if their average cost of deposits increased. The persistent competitiveness of small banks is related to their aggressive and apparently more profitable loan growth.

More recently, DeYoung and Hunter (2002) and DeYoung et al. (2003) examine the comparative strengths and weaknesses of large and small banks (in the new more competitive and technological world) and outline a stylized "strategic map" of the banking industry that summarizes the past, present and potential future impact of environmental changes on the structure of the banking industry. Such a strategic framework supports the idea that well-managed community banks can financially outperform large commercial banks. The authors conclude that the community business model is financially viable and that well-managed community banks are likely to survive in the future.

The only available study based on an international sample has been recently performed by the IMF; however, the study concentrates on a specific sub-sample of small banks, e.g. the cooperative banks, and confirms that cooperative banks are a growing part of many financial systems and show a lower volatility of returns (Hesse and Čihák, 2007).

Outside the US, Pastré (2001) describes how "small is beautiful", while Bonaccorsi di Patti et al. (2005) empirically study the determinants of Italian small banks' out-performance in loan growth with respect to larger banks.

The former study is a simple list of what Pastré calls the "six commandments" for small banks' survival: 1) avoid businesses where economies of scales are predominant; 2) be specialized; 3) be flexible; 4) avoid taking too much risk; 5) develop banking networks; 6) price risk correctly.

The latter is an empirical investigation of what drives the rising loan and deposit market share of Italian small banks. The authors examine multiple demand and supply factors seemingly 
correlated to the different loan growths experienced by small and large banks and conclude that small banks' out-performance mainly depends on large banks' loss of market grip. This group of banks is indeed facing restructuring and re-organizing problems after their M\&A operations and the introduction of more advanced risk management techniques encouraged by the new regulatory rules for capital adequacy (Basle 2). Therefore, Italian small banks' best performance appear to be a transitory phenomenon. As soon as large banks are back in action, small banks will lose their advantage.

Indeed, Italy may represent a natural case-study. The process of consolidation among large banks has been impressive: between 1990 and 2001 more than 500 M\&A occurred among banks accounting for $50 \%$ of total funds intermediated by the entire banking system (Panetta, 2005); however, almost all large Italian banks are still national champions which concentrate more than $80 \%$ of their activities in national boundaries where, given the typical small size of Italian firms, they naturally operate in the same credit markets of small banks. On the other hand, somehow unexpectedly, small Italian banks have been increasing their loan and deposit market shares. As the Bank of Italy details in recent Annual Reports, smaller banks have been recording higher rates of growth in lending to firms and households than did other intermediaries. In 2004, small banks accounted for three quarters of new business; in 2005 they accounted for about half of the growth in lending to the private sector. As a consequence their market share increased both in lending to small firms and in loans to medium-sized and large companies ${ }^{2}$ : they accounted for $25 \%$ of total loans in 1999 and for $1 / 3$ of total loans in 2005.

As the Italian small banking group is extremely heterogeneous, comprising credit cooperatives or joint-stock banks, specialized or universal banks, independent banks or banks affiliated to large groups, it is useful to investigate the drivers of their increased loan market share. Although small banks have taken advantage from their large competitors' retreat, as highlighted by

\footnotetext{
${ }^{2}$ Bank of Italy, Annual Reports (2004; 2005).
} 
Bonaccorsi di Patti et al. (2005), our analysis can help to underline the specific features that can provide small banking institutions with a viable and successful survival strategy in an era of consolidation.

In the following section, we discuss our hypothesis and data sources used in this investigation.

\section{Hypothesis and research design}

Our paper address the main question of how David can be successful in a Goliath world by analysing two broad sets of issues. First, we address the question of whether relationship lending can help explain small banks increase in loan market share. Second, we investigate whether the conquest of loan market share has been done to the detriment of bank profitability and risk. In this section, we set out a discussion of the main testable hypothesis, describe the methodology and define the variables used in the empirical analysis.

First of all, we analyse the impact of small bank characteristics (ability to develop relationship lending) on their loan growth.

A substantial literature suggests that the development of strong bank-firm relationship helps the intermediation process via reduced information asymmetries and agency problems (Diamond, 1984; Boot, 2000). As Berger and Udell (2002, p.1) state, "relationship lending is one of the most powerful technologies available to reduce information problems in small firms finance [...]. Under relationship lending, banks acquire information over time through contact with the firm, its owner, its local community on a variety of dimensions and use this information in their decisions about the availability and terms of credit to the firm". Therefore relationship lending is nested with the use of "soft information", i.e. information that cannot be easily observed, verified and credibly transmitted from one agent to another. In markets characterized by strong competition and powerful pressures towards concentration (which means losing independency, for a small bank perspective) on the one 
side, and an industrial structure based on small businesses, on the other side, specializing in relationship lending may prove strategic in surviving or even thriving. Small banks increasing their loan growth should be the ones who invest in relationship lending.

The first testable hypothesis follows:

H1: small bank loan growth is positively affected by the bank's ability/willingness in investing in intense lending relationships.

Small banks are deemed to be apter than large banks to develop relationship lending because they generally operate in a small community and are owned and/or managed by community members. Three sub-hypothesis are at work: "the long-term interaction hypothesis" (Banerjee et al., 1994; Besley and Coate, 1995), the "peer monitoring hypothesis" (Stiglitz, 1990; Hoff and Stiglitz, 1990) and the "functional proximity hypothesis" (Alessandrini et al, 2005). In the first case, taking active part in the life of a community, the bank shares relations of various kind, not only economic, through which relevant (and not necessarily hard) information can be acquired and used in its lending activity. Focusing on a different mechanism, the peer monitoring hypothesis considers a contract for which each member may continue to benefit from her loan only if all the others' projects are successful, so members have an incentive to control each other. Making loans mainly to its members, a credit cooperative levers on the control incentive that neighbours face, thus contributing to a high loan repayment record. Effective peer monitoring is facilitated by the small size and the small area of operations of most credit cooperatives. Finally, the third hypothesis points out that bank organizational structure matters. As soft information is difficult to transmit and relationship lending is mainly based on "soft data", relationship lending need to be associated with a fundamentally different lending process - than transaction-based lending - and therefore it requires a different organizational form (Ferri, 1997; Berger and Udell, 2002; Berger et al., 2002; Stein, 2002; Scott, 2004). This stream of literature argues that large hierarchical firms (banks) may be at a disadvantage in transmitting the type of soft information associated with relationship lending, while 
there is a strong incentive for soft-information production in small organizations. However, small size may not be a sufficient condition; the functional proximity between the local system where the bank operates and the decisional centre of the same bank might be relevant, as shown by Keeton (1995) and Alessandrini et al. (2005). Functional proximity concerns all banks that, given the localization of their decisional centre and strategic functions, are close to the areas where they operate. Being a small local bank is not a sufficient condition for being functionally proximate to its territory: if the bank belongs to a banking group, whose decisional centre and strategic functions are far from the bank's territory, intrabank governance mechanisms may affect the credit process of the local affiliate up to the point that soft-information is no longer captured and used, with the final effect that credit to small, young, opaque firms is dampened. This suggests the second testable hypothesis:

H2: small bank loan growth is positively affected by the local status of the bank. Finally, in a more competitive market, the choice about the business strategy becomes more relevant. A bank is mainly faced with two choices: diversify or specialize. In the last two decades product and market diversification has spread across the banking industry: mainly large, but also small banks have tried to increase the scope of their supply in order to offer their customers a greater variety of services while, at the same time, achieving cost and revenues economies of scope. However, there is no definitive evidence for the existence of scope economies (Berger and Humphrey, 1997; Berger, Demsetz and Strahan, 1999). As a matter of fact, a recent trend in the banking industry is toward a re-focusing or "returning to the core" strategy. Small banks are faced with different strategies: specialize in lending, specialize in retail/private banking services, be a universal bank. In such a perspective, an increase in loan market share may depend on the fact that small banks have embraced a specific lending-oriented strategy.

The third empirical prediction follows:

H3: small bank loan growth is increasing with its commitment in specializing in lending. 
In sum, we posit that, in terms of loan growth, best performers in the small banking group are those banks who are good at ripening the hypothesized small bank structural advantages discussed above.

All predictions are tested through a traditional OLS and an ordinal logistic regression. In the first model, the dependent variable is the average loan growth that each bank experiences during the sample period (1989-2004) and is regressed on a vector of variables proxies for the following dimensions: Relationship Lending; Local Status; Strategy, Control Variables (see table 1). However, as we are interested in ascertaining whether the different degrees of loan growth amongst the small banking group could be ascribed to differences in the use of their structural characteristics, the same exercise is run using an ordinal logit regression. Ordinal logistic regression assumes that the outcome variable can take on $\mathrm{K}+1$ values coded $0,1,2,3 \ldots . \mathrm{K}^{3}$. In our study, the outcome variable (extent of loan growth) ranges from low to moderate to strong. Slow banks are defined as those which, at most, are able to mimic large banks loan growth; moderately fast bank are faster than the previous category and yet are slower than those banks experiencing a loan growth higher than the sample median. By use of a polytomous outcome variable we are able to identify the drivers of survival for small banks both within the small banks group and in comparison with the average rate of growth experienced by larger banks in the same period. In such a specification, the dependent variable is as follows:

$$
=1 \text { if } \mathrm{g} \leq \mathrm{g}_{1} \quad \text { slow banks }
$$

$\mathrm{Y}($ extent of bank $\mathrm{j}$ loan growth $) \quad=2$ if $\mathrm{g}>\mathrm{g}_{1}$ and $\mathrm{g}<\mathrm{g}_{2}$ moderately fast banks

$$
=3 \text { if } \mathrm{g} \geq \mathrm{g}_{2} \quad \text { fast banks }
$$

\footnotetext{
${ }^{3}$ It differs from a classical polytomous logistic regression in the fact that the outcome variable has a natural ordering among the K levels: common examples of ordinal outcomes include variables such as the extent of disease (none, some, severe), job performance (inadequate, satisfactory, outstanding); opinion on some issues (strongly disagree, disagree, agree, strongly agree).
} 
where $\mathrm{g}$ is bank $j$ loan growth; $\mathrm{g}_{1}$ is the average loan growth experienced by large banks during the same sample period $(6,6 \%)^{4} ; \mathrm{g}_{2}$ is the median loan growth of our sample of banks. As before, independent variables are proxies for Relationship Lending; Local Status; Strategy, Control Variables.

A second step of our analysis investigates the relationship between loan growth and profitability and credit risk. We explore possible combinations of "Non Performing Loans over Gross Loans" and "ROE” associated with a higher or lower probability of high loan growth.

A classification and regression tree (CART) is used for this purpose. CART, a nonparametric regression and classification method originally introduced by Breiman et al. (1984), has a number of advantages over traditional parametric regression methods because it allows the relaxation of underlying assumptions, revealing interactions of covariates, and using them to improve the quality of the model ${ }^{5}$.

CART is particularly well suited for our purposes because, by simultaneously identifying significant clusters that exhibit relevant differences with respect to the dependent variable, it provides a unique insight into profitability and risk patterns that can be identified in the data. In other words, we are able to split our dataset into relevant and homogeneous clusters that exhibit significant differences in their Non Performing Loans (NPL)/Gross Loans ratio and ROE with respect to the likelihood of being fast banks. One potential drawback of CART rests in the fact that it requires a dichotomous dependent variable; consequently our tri-partition between slow, moderately fast and very fast banks has been collapsed into a binary variable, taking the value 1 if the bank is very fast and zero if the bank loan growth is below the value of the sample median. In other words, slow and moderately fast banks belong to the same partition (group). However, at this

\footnotetext{
${ }^{4}$ See Bonaccorsi di Patti et al. (2005). During the same period, the entire population of small banking institutions benefited from a loan growth equal to $14 \%$.

${ }^{5}$ In CART, the sample of subjects is systematically sorted into completely homogeneous subsets until a saturated tree is found. For each split, CART considers the entire set of available predictor variables to determine which one maximizes the homogeneity of the following two daughter nodes. This is a hierarchical process that reveals interdependencies between covariates. The process is continued until the nodes are completely homogeneous and cannot be split any further. See Breiman et al. (1984) for further details.
} 
point of the analysis such a tri-partition is no longer necessary or more informative than a bipartition. In fact, our final goal is to provide a criterion to verify whether the very fast group is sound enough to survive and prosper in the future.

CART enables to highlight the characteristics that better represent high performing/high growth banks (fit and fast), high performing/low growth banks (fit but slow), low performing/high growth banks (fat yet fast), low performing/low growth banks (fat and slow).

\subsection{Data description}

According to the Bank of Italy, the demarcation line between small and medium banks is set at $€ 7$ billions total assets. Banks whose total assets fall below such a threshold are defined "small and minor" banks, amounting to 778 banks in 2004. "Minor banks" are mainly credit cooperatives operating in just one province with one or few branches; "small banks" are a more diversified group comprising local banks, independent banks or banks belonging to large groups, branches of foreign banks and banks specialized in private banking or leasing/factoring, consumer credit and investment banking.

The Bankscope database covers more than 600 hundreds "small and minor" Italian banks, of which only 221 show data-series with no missing data during our sample period (1998-2004). These banks represent $16 \%$ of total loans (national figures) and $47 \%$ of the total loans lent by "small and minor banks". Except for foreign-controlled banks, all "small banks" are included in our sample (72 out of 126 banks), while the remaining are minor banks. However, a dimensional bias does not arise: our sample does not cover only the larger of the "small and minor banks"; indeed $45 \%$ of our sample has less than 10 branches and the average total assets is less than 1 billion euros, while the median total assets is less than 500 million euros.

While financial statement information is gathered from Bankscope, ownership and legal form information is taken from the Bank of Italy web site. Our sample period is 1998-2004. 


\subsection{Description of variables and descriptive statistics}

We first address the question of whether best performer in the small banking group are those banks who are better at ripening the hypothesized small bank advantages discussed in the prior section.

Variable definitions are summarized in Table 1.

Finding proxies for "Relationship Lending" is not an easy task. Prior empirical research has in fact studied relationship lending via field surveys addressed to samples of non-financial firms; in such studies, information on the number of bank relations in force and the duration of the bankfirm relationship were deemed good proxies for relationship lending. Absent such a set of information on banks' customers, as it generally happens in bank balance sheets, we follow deYoung, Hunter and Udell (2003) and define whether a bank specializes in relationship banking or focuses on transaction-based activity by looking at the "Net Interest Margin", i.e. the ratio of net interest income on total assets, and the ratio of "Loans to the Number of Bank's Employees". As the authors highlight, relationship lending generally requires a high touch, value added service supplied by the bank to its customers. Therefore it can expected that relationship loans require more attention and time by loan officers. All else being equal, high interest margins should be consistent with a high value added personalized banking strategy while low interest margins should be consistent with high volumes-low cost transactional banking strategies. Similarly, the lower the ratio of "Loans to the Number of Bank's Employees", the more intense the relationship lending, given that this tends to be more time consuming, in the bank's view, as opposed to transaction-based lending.

We are aware that several drawbacks arise with the use of the two above-said proxies.

First, high margins could reflect low competition in markets where the bank operates. A bank with a high degree of market power operates as price setter, irrespective to the chosen lending strategy. Therefore a control variable capturing the degree of market power enjoyed by our sample 
banks is added to the equation. "Degree of Market Power" is constructed, for each bank, as follows:

(Market Power) ${ }_{i}=\frac{\text { Number of branches in non provincial capitals }}{\text { Total number of branches }}$

We concentrate on branches in non-provincial capital as the number of banks operating in provincial capitals is quite high and increasing ${ }^{6}$. The same does not hold true when considering small municipalities and villages, where banks may still enjoy local monopoly power. Our expectation is that the higher the percentage of a bank's branches in non provincial capital, the higher its market power.

Second, using the Net interest margin as a proxy for relationship lending implies that that relationship loans are priced higher than transaction-based loans because their price include the value of the (relationship) services offered; however this may hold true if relationship loans show lower loan losses. In this respect we need to control for credit risk and therefore the ratio of "non performing loans/gross loans" is added.

Even in the case of the ratio "Loans to the Number of Bank's Employees" a drawback exists, since a low ratio may reflect a bank's inefficiencies or even the presence of diseconomies of scale. The "Cost Income" ratio is therefore added to the equation in order to control for bank's efficiency, while diseconomies of scale are controlled by the natural logarithm of Total Assets.

The extent of a bank "Local Status" is proxied by two dummy variables: Cooperative and Thinking Head. The former takes the value 1 if a small bank is a credit cooperative and zero otherwise and represents a proxy for both the "long-term interaction hypothesis" and the "peer monitoring hypothesis" (Angelini et al., 1998). Second, we posit that being independent, i.e. not belonging to a group, increases a bank's ability to capture and use soft-information in lending

\footnotetext{
${ }^{6}$ The number of bank branches has been continuously increasing starting from 1990 and it has mainly concerned large municipalities and provincial capitals.
} 
decisions. Following Alessandrini et al.(2005) "Thinking Head" is a dummy variable that takes the value 1 if a bank is independent or head of a group and zero if it belongs to a group.

The strategy of focusing in lending activity can be detected by three different variables: the ratio of loans to total assets, the ratio of net interest revenue to total revenue and leverage. The first ratio helps detect the existence of a consolidated strategy in the business of lending and should reflect positively on a bank loan growth. Higher values of the second ratio are signs of a strategy diversifying-oriented which could help delivering a relationship approach. In fact, a bank that increases its supply by distributing a range of services without reducing its propensity to lend is positively perceived by customers as a true universal bank where one-stop-shopping is possible. Finally, fast growing banks are expected to have a higher equity to total assets ratio to fund their riskier strategy.

Table 2 reports summary statistics for the explanatory variables over the years 1998-2004. We also break up our sample into "slow", "moderately fast" and "fast" banks according to whether their average loan growth over the sample period was respectively lower than the average loan growth experienced by large banks (6.6\%), ranged between $6,6 \%$ and the sample median, was higher than the sample median. A Kruskall-Wallis test for differences in medians is applied across the tri-partition. With reference to "slow" and "moderately fast" banks, "fast" banks are more likely to be better capitalized (Equity/Total Assets), less risky and more profitable in terms of ROE and ROA, making relatively more loans, as a percentage of total assets, show higher net interest margins, be more likely independent and credit cooperative banks. Last but not least, fast banks are significantly smaller than the other two partitions.

\section{Empirical Results}

\subsection{OLS and Logit results}


Tables 3 and 4 present the results of OLS and logit estimations, respectively. Standard errors are in parentheses. From our sample of 221 banks we excluded firms for which the required data were missing or that clearly presented outlying values; we therefore ended up with 195 banks.

Column 2 of Table 3 shows the results of our model specification as detailed in Section 3: the dependent variable, the 1998-2004 average loan growth, is regressed against proxies for relationship lending, localism, strategic patterns and control variables. All the variables in the equation show the expected sign with the exception of Cost Income; most of the proxies for structural peculiarities of small banking institutions are also statistically significant. In particular, loan growth is positively affected by being a credit cooperative, investing in relationship lending (net interest margin), specializing in lending while generating higher amounts of noninterest income, and being more capitalized. Being independent does not add to a bank's ability in using soft-information in its lending activity and loan growth: "Thinking Head" is in fact not statistically significant.

In order to check for the robustness of our estimates with respect to their power of capturing the extent of relationship lending net of banks' market power, we decided to estimate a second model. This is a two-stage model, where in the first-stage we regress "Net Interest Margin" on "Market Power" and "Credit risk"; in the subsequent, second-stage, the estimated residuals are included as an explanatory variable (proxy for relationship banking, net of market power and credit risk) for estimating the effects of relationship lending on loan growth. Results of this model are reported in column 3. Relationship lending is confirmed as a relevant variable for loan growth.

Table 4 presents the results of the ordinal logit regression with the same specifications used in the OLS exercise. The ordinal dependent variable classifies our sample of banks according to their loan growth: slow banks - with a loan growth $\leq$ the average loan growth experienced by large banks in the same period $(6,6 \%)$; moderately fast banks - with a loan growth ranging between $6,6 \%$ and the sample median; fast banks - with a loan growth higher than the sample median. 
The logit model shows a good predictive power: $60 \%$ of banks are correctly classified, while Nagelkerke R-squared is equal to $39 \%$. All the variables in the equation show the expected sign and results confirm that different degrees of loan growth amongst the small banking group are driven by relationship lending, localism (dummy cooperative), and strategy. For instance, the estimated coefficient of the variable "cooperative" means that non cooperative banks are less than $1 / 12$ as likely to have a higher loan growth compared with cooperative banks. ${ }^{7}$ In sum, the more banks lever on their structural characteristics, the higher their loan growth.

Column 3 presents a second specification of the logit model, where the two proxies for localism - cooperative and thinking head - are substituted by a polytomous variable, named "Degree of Localism" able to directly capture both aspects of localism. The new variable takes the value 0 when a bank is neither independent nor cooperative (no localism); the value 1 when the bank is both independent and cooperative (strongest degree of localism); the value 2 when the bank is independent and yet not cooperative (mild degree of localism); the value 3 when the bank is cooperative but not independent ${ }^{8}$.

\begin{tabular}{|l|l|c|c|}
\hline \multicolumn{2}{|l|}{ Degree of Localism } & \multicolumn{2}{c|}{ Thinking head } \\
\hline \multicolumn{2}{|c|}{} & $\mathbf{0}$ & $\mathbf{1}$ \\
\hline \multirow{2}{*}{ Cooperative } & $\mathbf{0}$ & 0 & 2 \\
\cline { 2 - 4 } & $\mathbf{1}$ & 3 & 1 \\
\hline
\end{tabular}

Previous results are confirmed while the new variable uncover the effect of being independent or thinking head. In fact, being strongly local (both cooperative and independent) has a stronger positive effect on a bank's loan growth than being just independent (or mildly local); at the same time, independent banks are better off with respect to small banks belonging to groups as the negative sign of the coefficient for "Degree of localism=0" highlights.

\footnotetext{
${ }^{7}$ The logistic coefficients can be interpreted as the change in the log odds associated with a 1 unit change in the independent variable. Since its easier to think of odds rather than log odds, the $e$ raised to the power of $\mathrm{B}_{i}$ is the factor by which the odds change when its independent variable increases by 1 unit.

${ }^{8}$ This category cannot have observations at all and is not reported in table 4.
} 


\subsection{Classification tree results}

CART tree is shown in graph 1 and the results are summarized in table 5. Our sample is partitioned into five groups, according to their profitability and risk patterns with respect to the likelihood of being fast growing banks. Therefore, we end up with five clusters of banks exhibiting the following strategies with respect to loan growth, profitability and credit risk (table 5):

Group 1: fat and slow: the cluster exhibits a low loan growth and a high level of NPL to gross loans;

Group 2: semi-fit and fast: on average the cluster exhibits high loan growth, combined with the highest ROE $(>7 \%)$ and a medium level of NPL to gross loans (laying in the interval $4 \%-14 \%$, with a mean of $5,22 \%)$;

Group 3: fat yet fast: on average the cluster exhibits high loan growth combined with a low performance in both ROE and NPL to gross loans;

Group 4: semi-fit and fast: on average the cluster exhibits high loan growth, combined with a medium ROE and the lowest level of NPL to gross loans;

Group 5: semi-fat and slow: on average the cluster exhibits a low loan growth, combined with a medium ROE and a medium level of NPL to gross loans.

\subsection{Logit and CART analyses combined}

A further step of our analysis combines the results of the logit exercise with those of the CART analysis: our aim is to verify how the various small banks' peculiarities and strategic patterns in lending activity, that proved to be significant in explaining small banks' high loan growth, are allocated among our clusters. Each cluster's characteristics are reported in table 6. A ttest for differences in means is also reported. If all the above mentioned characteristics hold true, 
potential differences in means between the entire fast group (column II) and the fast clusters (G-2; G-3; G-4) should show no statistical significance. On the contrary, we expect statistically significant differences in mean values between the two slow clusters (G-1 and G-5) and the entire fast group.

The two best performer clusters (G-2 and G-4) differ in their choice of profitability (ROE) and risk (NPL/Loans). G-4 banks show a more prudent strategy: they target a lower risk-return combination and maintain a higher capital ratio. This result is obtained notwithstanding the lower presence of credit cooperatives in the cluster, i.e. banks which are well known for their low appetite for risk and are not subject to the constraint of maximizing shareholders' value. An alternative explanation of the different strategies adopted by G-2 and G-4 may reside in the fact that G-2 comprises a higher percentage of banks affiliated to groups ( $24 \%$ and $13 \%$ respectively): a parent bank may be prone to short-termism in the trade-off between profitability and risk.

G-3 comprises few banks (7), most of which belong to large bank groups and tend to be specialized in corporate or private banking. All the banks in the cluster are characterized by very low ROE (mean value $0.35 \%$, standard deviation $1.8 \%$ ).

G-1 and G-5 clusters share similar value for ROE (5\%), while G-1 banks exhibit the highest level of NPL on gross loans $(20.02 \%)$, which is in part due to the fact that the group comprises the highest percentage of banks located in regions where credit risk is systematically higher (Southern regions) and a lower percentage of credit cooperatives.

The fast growth of the two "virtuous" groups (G-2 and G-4) goes hand in hand with a greater propensity to lever on relationship lending (either highest Net Interest Margin or lowest ratio of Loans/N. of Employees), with the strongest local status (highest percentage of cooperatives), with greater focus on lending activity (Loans/Total assets). G-2 and G-4 are truly fast groups: those banks classified as zero in graph 1 belong to the moderately fast group as defined in the first part of 
the empirical analysis, e.g. out of 85 banks belonging either to G-2 or G-4, $27^{9}$ experience a loan growth below the value of the sample median but higher than the average growth of large Italian banks. These banks share the very same characteristics of risk-return with very fast (and semi-fit) banks and yet they do not grow at the same rate. In fact, they do not lever on relationship lending, degree of localism, etc....with the same degree of very fast banks as shown by the ordinal logit exercise. Indeed, this help explain why not all the mean values of our proxies for local status, relationship lending and strategic patterns are statistically "equal" to the sample mean of the entire fast group.

Similarly, G-3 banks' fast growth do not seem to be driven by relationship lending or localism; besides, it is not founded on good fundamentals, too. Indeed, their growth is less likely to be tenable in the future.

Finally, the slow performance of G-1 and G-5 could be ascribed to the absence or a misuse of those structural factors that should characterize small banks. In fact, G-1 and G-5 comprise 21 slow banks, 52 moderately fast banks and 30 very fast banks ${ }^{10}$. Notwithstanding their different growth patterns, these banks are similar in their being "fat" in terms of ROE and risk. In other words, levering on relationship banking, proximity, or focusing on lending is a necessary condition for loan growth, yet it is not a sufficient one in order to sustain such a growth in the long run.

Combining together all the potential drivers of small banks' recent exceptional growth, a "strategic map" can be constructed (Table 7). The map is $3 \times 3$ matrix which considers, on the one side, the "transitory factors hypothesis" - i.e., large banks are facing (transitory) organizational problems and left room to small banks growth - and, on the other side, the "structural factors hypothesis", - e.g. small banks can lever on their own specificities, combined with an ability to control risk and profitability, in order to survive and flourish even in a more inhospitable world -.

\footnotetext{
${ }^{9}$ These are the 0 clusters of G-2 and G-4: respectively 21 (out of 22) and 6 (out of six). See graph 1 . Only one bank (belonging to G-2) shows a loan growth below the $6.6 \%$ threshold.

${ }^{10}$ These latter are the 1 clusters of the two groups: respectively 5 and 25 . See graph 1 .
} 
Such analysis allows to make use of the initial tri-partition between "slow", "moderately fast" and "very fast" banks. In fact, banks can react to their larger competitors' transitory difficulties by showing a fast loan growth, a moderate loan growth or a slow loan growth ${ }^{11}$. Therefore, banks in each cluster are analysed and re-classified according to their loan growth. For instance, all G2 and G4 banks show either a fast or a moderately fast loan growth and are to be assigned to the first and second column of Table 7. Their exact position within the matrix is now determined by the results of the logit exercise, which has shown that the higher the exploitation of structural factors, the more likely the bank's loan growth. Therefore, "very fast" banks in G2-G4 clusters are allocated in the left upper cell while "moderately fast" banks in G2-G4 are assigned in the central cell.

Making use of such a "strategic matrix", our study provides a criterion to highlight which small bank business model is still economically viable. As a matter of fact, it appears that $29 \%$ of our entire sample of small banks will be able to survive and prosper even when the causes of large banks' difficulties will disappear. Other strategic paths can be sketched as follows. First, $14 \%$ of the sample, made up of moderately fast banks, could easily follow the leaders if these banks were to invest more on structural factors. Second, absent structural determinants of growth, banks may evolve in subsequent paths implying a reduction of their loan growth, with a final, unavoidable, way out. This appears to be the most likely immediate fate for a $12 \%$ of our sample, given their low growth, bad fundamentals and scarce reliance on relationship lending. For the remaining banks (45\% of sample), investing in structural drivers of growth represents the crucial choice that these banks will face in order to survive in the next future.

\section{Conclusions}

\footnotetext{
${ }^{11}$ Where a bank is defined as fast, moderately fast and slow according to their loan growth: slow banks - with a loan growth $\leq$ the average loan growth experienced by large banks in the same period $(6,6 \%)$; moderately fast banks - with a loan growth ranging between $6,6 \%$ and the sample median; fast banks - with a loan growth higher than the sample median.
} 
This study provides a two-step evaluation of the potential for survival of small banks in a Goliath world.

In the first step, we demonstrate that most of the peculiarities of small banks, i.e. localism and relationship lending, are good explanatory variables of their recent high loan growth. Exhibiting strategies focusing on lending activity and being more capitalized matters as well.

The second step explores the relationship between loan growth and profitability and credit risk. We end up with five groups of banks that exhibit the following strategies: a) two semiFit \& Fast clusters: high performing banks - in terms of low NLP/Loans and high ROE- with high loan growth; b) one Fat and Fast cluster - low performing banks with high loan growth; c) two Fat and Slow clusters - low performing banks with low loan growth.

In sum, the small banks' group is not homogeneous in its loan growth which, for best performer, is driven by structural factors, such as the ability to lever on their local status, on relationship lending and to control credit risk while pursuing a good level of profitability as well.

As such, their growth may not be a transitory phenomenon, depending on the fact that large Italian banks are facing difficulties in maintaining their market share due to potential organizational diseconomies combined with a possible reconsideration of their lending policies, more centred on the use of credit scoring techniques. Making use of a "strategic matrix", our study provides a criterion to highlight which small bank business model is still economically viable. In fact, it appears that $44 \%$ of our sample of small banks will be able to survive and prosper even when the causes of large banks' difficulties will disappear, thanks to their ability of levering on those structural drivers of growth such as relationship lending. Our study confirms the results obtained in the US market (deYoung, Hunter, Udell, 2003), e.g. small bank business model is still viable even in a world of Goliaths but it takes a well-run organizations to make it work. 


\section{References}

Alessandrini, P., Croci, M., Zazzaro, A., (2005), “The geography of banking power: the role of functional distance", paper presented at AAG 2005 Conference, Denver, Colorado.

Angelini, P., Di Salvo, R., Ferri, G., (1998), “Availability and cost of credit for small businesses: customer relationships and credit cooperatives", Journal of Banking and Finance, 22: 925-54.

Avery R. B., Samolyk K.A., (2004), "Bank consolidation and small business lending: the role of community banks", Journal of financial services research 25, 291-325

Banca d'Italia, (2004; 2005), Annual Reports, Rome.

Banerje A.V., Besley T., Guinnane T.W, (1994), “Thy neighbor's keeper: the design of a credit cooperative with theory and a test”, Quarterly Journal of Economics 109, 491-515.

Basset B., Brady, T., (2002), "What drives the persistent competitiveness of small banks?", The Federal Reserve Board, Finance and Economics Discussion Series n.28

Berger, A. N., Humphrey D.B., (1997), "Efficiency of Financial institutions: international survey and directions for future research", European Journal of Operational Research, 98: 175-213.

Berger, A. N., Demsetz R.S., Strahan, P.E., (1999), "The consolidation of the financial services industry: causes, consequences and implications for the future", Journal of Banking and Finance, $23: 135-194$

Berger, A.N., Miller, N.H Petersen, M.A. Rajan, R.G., J.C. Stein, (2002), “Does Function Follow Organizational Form? Evidence from the Lending Practices of Large and Small Banks", NBER Working Paper No. W8752.

Berger, A.N., Udell G.F., (2002), "Small Business Credit Availability and Relationship Lending: The Importance of Bank Organizational Structure", The Economic Journal, 112: F32-F53. 
Berger, A.N., Saunders A. Scalise J.M., Udell, G.F, (1998), “The effects of bank mergers and acquisitions on small business lending”, Journal of financial economics 50,187-229.

Besley T., Coate S., (1995), “Group lending, repayment incentives and social collateral”, Journal of development economics 46, 1-18.

Bonaccorsi di Patti E., Eramo, G., Gobbi, G., (2005) "Piccole e grandi banche nel mercato del credito in Italia dal 1996 al 2003”, Banca Impresa Società n 12005.

Bonaccorsi di Patti, E., Gobbi, G., (2001), “The Changing Structure of Local Credit Markets: Are Small Business Special?”, Journal of Banking and Finance, 25: 2209-2237.

Boot A. W.A., (2000), “Relationship banking: what do we know?", Journal of financial intermediation 9, 7-25.

Breiman L. F., Olshen, Stone, (1984), Classification and Regression trees, Belmont (CA-USA), Wadsworth International Group, Statistics/probability Series

DeYoung, R., Hunter, W.C., (2002), "Deregulation the internet and the competitive viability of large banks and community banks.", in The future of banking, ed. Benton Gup, Greenwood Press Quorum Books.

DeYoung R., Hunter, W.C., Udell, G.F., (2003), “The Past, Present and Probable Future for Community Banks", Federal Reserve Bank of Chicago WP 2003-14.

DeYoung, R, Goldberg L G., White, L. J., (1999) "Youth adolescence and maturity at banks: credit availability to small business in an era of bank consolidation”, Journal of banking and finance 23, 463-492.

Diamond D. W., (1984), "Financial intermediation and delegated monitoring”, Review of Economic Studies 51, 393-414.

Ferri, G., (1997), "Branch manager turnover and lending efficiency: local vs. national banks”, $B N L$ Quarterly Review, Special Issue, March: 229-47. 
Focarelli D., Panetta F., Salleo C., (2002), "Why do banks merge: some empirical evidence from Italy", Journal of Money credit and Banking 34, n.4, 1047-1066.

Fox, J. (1997), Applied Regression Analysis, Linear Models, and Related Methods, Thousand Oaks: Sage.

Gobbi G., Lotti F., (2004), “L'ingresso nei mercati locali: le strategie delle banche”, Cooperazione di credito $183,115-135$.

Goldberg L G.,White L. J., (1998), “The novo banks and lending to small businesses”, Journal of banking and finance 22, 851-867.

Hesse, H., Čihák, M. (2007), “Cooperative banks and financial stability”, IMF working paper $W P / 07 / 2$

Hoff K., Stiglitz J.E., (1990), “Introduction: imperfect information and rural credit markets. Puzzles and policy perspectives", World bank economic Review 4, 235-250.

Keeton W.R., (1995), "Multi-office bank lending to small businesses: some new evidence", Federal reserve bank of Kansas City Economic Review 80 (“), 45-57.

Ongena, S., Smith, D.C., (2000), "Bank relationships: a review", in T.H. Patrick and S. A. Zenios (eds.), Performance of financial institutions: efficiency, innovation, regulation, 221-258.

Panetta F., 2005 (ed), Il sistema bancario italiano negli anni novanta, Bologna il Mulino.

Pastré O. , (2001), "Industrie bancaire: les espoirs des Davids face aux Goliaths? », Revue d'Economie financière, 1-10.

Petersen, M.A., Rajan R.G., (1995) "The effect of credit market competition on lending relationships", Quarterly Journal of Economics 110, 407-443.

Peek, J. , Rosengren, E.S., (1998), “ Bank consolidation and small business lending: it’s not just bank size that matters", Journal of Banking and Finance, 22, 799-819. 
Sapienza P., (2002) "The effects of banking mergers on loan contracts", The Journal of Finance, 57, n.1, 329-367.

Scott, J.A., (2004), "Small business and the value of community financial institutions", Journal of Financial Services Research 25: 207-30.

Stein, J.C., (2002), "Information Production and Capital Allocation: Decentralized versus Hierarchical Firms”, Journal of Finance, 57: 1891-1922.

Stiglitz J.E., (1990), “Peer monitoring in credit markets”, World Bank Economic Review 4, 351-366.

Sheskin, D.J., (2000), Handbook of Parametric and Nonparametric Statistical Procedures., Boca Raton et. al. : Chapman \& Hall. 
Tables and figures 
Table 1 Independent variables: definition of the variables and expected sign of coefficients

\begin{tabular}{|c|c|c|c|c|}
\hline & \multirow[t]{2}{*}{ Variable name } & \multirow{2}{*}{$\begin{array}{l}\text { Definition } \\
\text { The ratio of net } \\
\text { interest revenue on } \\
\text { total assets }\end{array}$} & \multicolumn{2}{|c|}{ Expected effect on loan growth } \\
\hline \multirow{2}{*}{$\begin{array}{l}\mathbf{R} \\
\mathbf{E} \\
\mathbf{L} \\
\mathbf{A} \\
\mathbf{T} \\
\mathbf{0} \\
\mathbf{N} \\
\mathbf{S} \\
\mathbf{S} \\
\mathbf{P}\end{array}$} & & & + & $\begin{array}{l}\text { Greater attention to relationship lending is } \\
\text { the driver of high loan growth: the higher } \\
\text { the interest margins the most probable a } \\
\text { high value added personalized banking } \\
\text { strategy is at work with positive effects on } \\
\text { loan growth }\end{array}$ \\
\hline & $\begin{array}{l}\text { Loans / Number } \\
\text { of employees }\end{array}$ & $\begin{array}{l}\text { The ratio of Loans to } \\
\text { the number of bank's } \\
\text { personnel (in natural } \\
\text { logarithms) }\end{array}$ & - & $\begin{array}{l}\text { Greater attention to relationship lending is } \\
\text { the driver of high loan growth: the lower } \\
\text { the number of loans per personnel the most } \\
\text { probable a high value added personalized } \\
\text { banking strategy is at work with positive } \\
\text { effects on loan growth }\end{array}$ \\
\hline & Cooperative & $\begin{array}{l}\text { Dummy variable that } \\
\text { takes the value } 1 \text { if a } \\
\text { bank is a cooperative } \\
\text { and } 0 \text { otherwise }\end{array}$ & + & $\begin{array}{l}\text { Proxy for the positive effects of "peer } \\
\text { monitoring" and "long term" hypotheses } \\
\text { on banks' lending patterns }\end{array}$ \\
\hline & Thinking Head & $\begin{array}{l}\text { Dummy variable that } \\
\text { takes the value } 1 \text { if a } \\
\text { bank is independent } \\
\text { and } 0 \text { if it belongs to } \\
\text { a group }\end{array}$ & + & $\begin{array}{l}\text { Decision-making autonomy can foster } \\
\text { bank's ability to use soft information in its } \\
\text { lending activity }\end{array}$ \\
\hline & $\begin{array}{l}\text { Loans/Total } \\
\text { Assets }\end{array}$ & $\begin{array}{l}\text { The ratio of Loans to } \\
\text { Total assets }\end{array}$ & + & $\begin{array}{l}\text { A strategy that focus on lending activity } \\
\text { reflects positively on loan growth }\end{array}$ \\
\hline & $\begin{array}{l}\text { Net Interest } \\
\text { Revenue/ Total } \\
\text { Revenue }\end{array}$ & $\begin{array}{l}\text { The ratio of net } \\
\text { interest revenue to } \\
\text { total revenue }\end{array}$ & - & $\begin{array}{l}\text { Lower values are signs of strategy that } \\
\text { focuses on diversification in order to } \\
\text { improve the relationship approach }\end{array}$ \\
\hline & $\begin{array}{l}\text { Equity /Total } \\
\text { Assets }\end{array}$ & $\begin{array}{l}\text { The ratio of bank's } \\
\text { equity to total assets }\end{array}$ & + & $\begin{array}{l}\text { Faster banks need more capital to fund } \\
\text { their (riskier) strategy }\end{array}$ \\
\hline$y$ & Total Assets & $\begin{array}{l}\text { Total assets (in } \\
\text { natural logarithms) }\end{array}$ & $?$ & Dimension matters? \\
\hline & Cost / Income & Cost income ratio & - & $\begin{array}{l}\text { More efficient banks are deemed to grow } \\
\text { faster }\end{array}$ \\
\hline$\underset{R}{A}$ & Market Power & $\begin{array}{l}\text { The ratio of the } \\
\text { number of branches } \\
\text { in non provincial } \\
\text { capitals over total } \\
\text { number of branches }\end{array}$ & + & Greater market power influence pricing \\
\hline & Credit risk & $\begin{array}{l}\text { The ratio of non } \\
\text { performing loans } \\
\text { over total loans }\end{array}$ & - & $\begin{array}{l}\text { Greater attention to relationship lending } \\
\text { should help in reducing adverse selection } \\
\text { of borrowers }\end{array}$ \\
\hline
\end{tabular}


Table 2 Summary Statistics

The following table presents means and medians for the explanatory variables over the sample period 1998-2004. Column 2 and 3 refer to the whole sample of 221 small banks. Columns 4-6 present medians for the tri-partition "slow growth", "moderate growth" and "fast growth" : specifically, banks are grouped within the "slow growth" group if their loan growth $\leq$ the average loan growth experienced by large banks in the same period $(6,6 \%)$; within the "moderate growth group if their loan growth ranges between $6,6 \%$ and the sample median; within the "fast growth group" if their loan growth is higher than the sample median. A Kruskall-Wallis test for differences in medians is applied across the tri-partition: statistical significance for the test at the $10 \%, 5 \%$ or $1 \%$ level are indicated by $*, * * ; * *$ respectively.

\begin{tabular}{|c|c|c|c|c|c|}
\hline & & & & & \\
\hline Variable & $\begin{array}{l}\text { Sample } \\
\text { mean }\end{array}$ & $\begin{array}{l}\text { Sample } \\
\text { median }\end{array}$ & $\begin{array}{l}\text { Median } \\
\text { when slow } \\
\text { growth }\end{array}$ & $\begin{array}{c}\text { median when } \\
\text { moderate } \\
\text { growth }\end{array}$ & $\begin{array}{c}\text { median when } \\
\text { fast growth }\end{array}$ \\
\hline Loan Growth 98-04 & 14.71 & 13.58 & 3.27 & 11.15 & 17.86 \\
\hline ROE & 7.04 & 6.81 & $4.73^{* * *}$ & $6.56^{* * *}$ & $7.70^{* * *}$ \\
\hline NPL/Gross Loans & 8.71 & 6.71 & $11.21^{* * *}$ & $7.10^{\star \star *}$ & $5.57^{* \star *}$ \\
\hline Total Capital ratio & 19.66 & 16.30 & 15.11 & 17.04 & 16.03 \\
\hline Net Interest Margin & 3.51 & 3.56 & $3.23^{* * *}$ & $3.52^{\star \star \star}$ & $3.64^{\star \star \star}$ \\
\hline Cost Income & 73.38 & 72.74 & 76.80 & 72.20 & 72.38 \\
\hline $\begin{array}{l}\text { Operating Costs/ Total } \\
\text { Earning Assets }\end{array}$ & 3.31 & 3.27 & 3.37 & 3.28 & 3.19 \\
\hline $\begin{array}{l}\text { Personnel Costs/ N. of } \\
\text { employees }\end{array}$ & 57.11 & 55.12 & 54.97 & 55.88 & 55.03 \\
\hline $\begin{array}{l}\text { Personnel Costs / } \\
\text { Total Assets }\end{array}$ & 1.63 & 1.65 & 1.57 & 1.62 & 1.67 \\
\hline $\begin{array}{l}\text { Loans/ N. of } \\
\text { employees }\end{array}$ & 2,510 & 2,036 & 1,771 & 2,022 & 2,101 \\
\hline ROA & .80 & 0.80 & $0.47^{* * *}$ & $0.77^{* * *}$ & $0.88^{* * *}$ \\
\hline $\begin{array}{l}\text { Net Interest Revenue } \\
\text { /Total Revenue }\end{array}$ & 77.25 & 78.81 & 76.83 & 78.97 & 78.83 \\
\hline Loans/Total Assets & 65.16 & 66.83 & $55.12^{* *}$ & $65.11^{\star \star}$ & $70.84^{\star \star}$ \\
\hline Equity/Total Assets & 13.96 & 12.72 & $9.63^{\star \star \star}$ & $12.57^{* * *}$ & $13.48^{* * *}$ \\
\hline Total Assets (th $€$ ) & 923,622 & 391,486 & $1,250^{* *}$ & $417,357^{* *}$ & $324,486^{* *}$ \\
\hline \multirow[t]{2}{*}{ N. of employees } & 283 & 100 & 264 & 126 & 93 \\
\hline & \multicolumn{5}{|c|}{ Frequency } \\
\hline N. banks & 221 & & 25 & 85 & 111 \\
\hline Cooperative (dummy) & 119 & & 5 & 42 & 72 \\
\hline $\begin{array}{l}\text { Thinking Head } \\
\text { (dummy) }\end{array}$ & 164 & & 11 & 64 & 89 \\
\hline Specialized (dummy) & 20 & & 8 & 4 & 8 \\
\hline North & 111 & & 9 & 45 & 57 \\
\hline Centre & 64 & & 5 & 23 & 38 \\
\hline South & 44 & & 11 & 17 & 16 \\
\hline
\end{tabular}




\section{Table 3. OLS results for loan growth(1)}

The dependent variable is the average loan growth over the period 1998-2004 for our sample of banks. In model I explanatory variables are proxies for localism, relationship lending activities, strategic patterns, control variables as reported in Table 2. Model II is a robustness check of our estimates to capture the extent of relationship lending net of banks' market power; it includes the residuals of a regression where "net interest margin" is the dependent variable and "market power" and "Non performing loans/gross loans" are the explanatory variables. Standard errors in parenthesis; statistical significance at the $10 \%, 5 \%$ or $1 \%$ level are indicated by *,**;*** respectively.

\begin{tabular}{|c|c|c|}
\hline & Model I & Model II \\
\hline Constant & $\begin{array}{c}-1,03 \\
(24,00)\end{array}$ & $\begin{array}{l}27.119 \\
(18.89)\end{array}$ \\
\hline Net Interest Margin & $\begin{array}{c}2.90 \\
(1.28)^{\star *}\end{array}$ & . \\
\hline $\begin{array}{l}\text { Residuals (Relationship } \\
\text { lending net of Market Power } \\
\text { and credit risk) }\end{array}$ & - & $\begin{array}{c}2.13 \\
(1.22)^{*}\end{array}$ \\
\hline Loans/n. of Employees (in log) & $\begin{array}{l}-0.70 \\
(2.90)\end{array}$ & $\begin{array}{l}-3.03 \\
(2.66)\end{array}$ \\
\hline Cooperative & $\begin{array}{c}3.66 \\
(1.68)^{\star *}\end{array}$ & $\begin{array}{c}5,09 \\
(1.62)^{* \star *}\end{array}$ \\
\hline Thinking Head & $\begin{array}{c}1.44 \\
(1.45)\end{array}$ & $\begin{array}{c}1.29 \\
(1.46)\end{array}$ \\
\hline Loans/Total Assets & $\begin{array}{c}0.10 \\
(0.06)^{*}\end{array}$ & $\begin{array}{c}0.16 \\
(0.06)^{* \star \star}\end{array}$ \\
\hline Equity/ Total Assets & $\begin{array}{c}0.79 \\
(0.07)^{\star * \star}\end{array}$ & $\begin{array}{c}0.81 \\
(0.07)^{\star * *}\end{array}$ \\
\hline $\begin{array}{l}\text { Net Interest Revenue /Total } \\
\text { Revenue }\end{array}$ & $\begin{array}{l}-0.32 \\
(0.08)^{\star * *}\end{array}$ & $\begin{array}{l}-0.35 \\
(0.07)^{\star * \star}\end{array}$ \\
\hline Total Assets (in log) & $\begin{array}{c}0.70 \\
(0.62)\end{array}$ & $\begin{array}{c}0.68 \\
(0.61)\end{array}$ \\
\hline Cost income & $\begin{array}{c}0.10 \\
(0.05)^{* *}\end{array}$ & $\begin{array}{c}0.05 \\
(0.05)\end{array}$ \\
\hline Market Power & $\begin{array}{l}-0.01 \\
(.02)\end{array}$ & - \\
\hline NPL/loans & $\begin{array}{l}-0.22 \\
(0,09)^{* *}\end{array}$ & - \\
\hline & & \\
\hline N. of observations & 195 & 195 \\
\hline R squared & $58,1 \%$ & $56.2 \%$ \\
\hline Durbin Watson Statistic & 2,097 & 2,080 \\
\hline
\end{tabular}

(1) Analysis of residuals confirms their Normal distribution; A weak collinearity between LOAN/TA and LOAN/n of employees is detected, with a VIF equal to 5.0; however, such a VIF level can be easily accepted as the typical critical value for multicollinearity is a VIF $\geq 10$ (Fox, J. (1997).

Eliminato: $\mathrm{N}$

Eliminato:

Eliminato: employess 


\section{Table 4 Logit results for loan growth.}

The dependent variable is a polytomous ordinal response that classifies our sample of banks according to their loan growth: slow banks - with a loan growth $\leq$ the average loan growth experienced by large banks in the same period $(6,6 \%)$; moderately fast banks - with a loan growth ranging between $6,6 \%$ and the sample median; fast banks - with a loan growth higher than the sample median. In model I explanatory variables are proxies for localism, relationship lending activities, strategic patterns, control variables as used in the OLS specification. In model II, the polytomous variable, "Localism Degree", substitutes the two dummies Cooperative and Thinking Head, taking the value 0 when a bank is neither independent nor cooperative, the value 1 when the bank is both independent and cooperative; the value 2 when it is independent and yet not cooperative. Standard errors in parenthesis; statistical significance at the $10 \%, 5 \%$ or $1 \%$ level are indicated by $*, * * ; * *$ respectively.

\begin{tabular}{|c|c|c|}
\hline & Model I & Model II \\
\hline $\begin{array}{l}\text { Residuals (Relationship } \\
\text { lending net of Market Power } \\
\text { and credit risk) }\end{array}$ & $\begin{array}{l}1.37 \\
(0.42)^{\star * *}\end{array}$ & $\begin{array}{l}1.37 \\
(0.42)^{\star * *}\end{array}$ \\
\hline Loans/n. of Employees (in log) & $\begin{array}{c}-1.50 \\
(0.91)^{*}\end{array}$ & $\begin{array}{c}-1.50 \\
(0.91)^{*}\end{array}$ \\
\hline Cooperative $=0$ & $\begin{array}{l}-2.47 \\
(0.58)^{\star * *}\end{array}$ & - \\
\hline Thinking Head $=0$ & $\begin{array}{c}-0.63 \\
(0.45)\end{array}$ & - \\
\hline Localism Degree $=0$ & - & $\begin{array}{l}-0.63 \\
(0.45)\end{array}$ \\
\hline Localism Degree $=1$ & & $\begin{array}{c}2.47 \\
(0.58)^{* * *}\end{array}$ \\
\hline Loans/Total Assets & $\begin{array}{c}0.05 \\
(0.02)^{\star * *}\end{array}$ & $\begin{array}{l}0.05 \\
(0.02)^{\star \star *}\end{array}$ \\
\hline Equity/ Total Assets & $\begin{array}{c}0.04 \\
(0.03)^{*}\end{array}$ & $\begin{array}{c}0.04 \\
(0.03)^{*}\end{array}$ \\
\hline $\begin{array}{l}\text { Net Interest Revenue /Total } \\
\text { Revenue }\end{array}$ & $\begin{array}{c}-0.06 \\
(0.02)^{* *}\end{array}$ & $\begin{array}{l}-0.06 \\
(0.02)^{* *}\end{array}$ \\
\hline Total Assets (in log) & $\begin{array}{c}0.25 \\
(0.20)\end{array}$ & $\begin{array}{c}0.25 \\
(0.21)\end{array}$ \\
\hline Cost income & $\begin{array}{c}-0.02 \\
(0.02)\end{array}$ & $\begin{array}{l}-0.02 \\
(0.02)\end{array}$ \\
\hline Growth $=1$ & $\begin{array}{l}-14.37 \\
(6.71)\end{array}$ & $\begin{array}{l}-11.90 \\
(6.71)\end{array}$ \\
\hline Growth $=2$ & $\begin{array}{l}-11.53 \\
(6.67)\end{array}$ & $\begin{array}{l}-9.07 \\
(6.67)\end{array}$ \\
\hline N. of observations & 195 & 195 \\
\hline Negelkerke R squared & $39.0 \%$ & $39.0 \%$ \\
\hline $\begin{array}{l}\text { Test of parallel lines }^{12} \\
\text { Null Hypothesis } \\
\text { Chi-square }\end{array}$ & $\begin{array}{c}302.09 \\
(7.45)\end{array}$ & $\begin{array}{c}302.09 \\
(7.45)\end{array}$ \\
\hline
\end{tabular}

${ }^{12}$ Test of the hypothesis that the location parameters are equivalent across the levels of the dependent variable. The results of the chi-square test statistic are not significant indicating that the assumption is tenable. 


\section{Table 5 Clusters' risk, profitability and loan growth rate}

Clusters' characteristics with respect to profitability and credit risk and their being fast or slow banks. Banks are defined as fast when their loan growth is higher than the sample median.

\begin{tabular}{|c|c|c|c|}
\hline ROE NPL/grossLoans & $>14 \%$ & ] $4,14 \%]$ & $<=4 \%$ \\
\hline$<=1,7 \%$ & & G3- fast banks & \\
\hline$] 1,7 \%-7 \%]$ & G1-slow banks & G5-slow banks & G4- banks \\
\hline$>7 \%$ & & G2 - fast banks & \\
\hline
\end{tabular}


Table 6 Clusters' summary statistics.

The following table reports mean values for a set of explanatory variables that help further characterize the five clusters identified via CART analysis. Columns 2 reports the mean values for the sample of fast banks: banks are defined as fast when their loan growth is higher than the sample median. A one sample t-test for differences in means is applied to each cluster with respect to the fast group: $\mathrm{H}_{0}$ : group mean = fast group mean; statistical significance at the $10 \%, 5 \%$ or $1 \%$ level are indicated by $* * * ; * *$ respectively. For categorical variables, a chi-square goodness of fit test is applied.

\begin{tabular}{|c|c|c|c|c|c|c|}
\hline & $\begin{array}{l}\text { Mean } \\
\text { when } \\
\text { fast }\end{array}$ & $\begin{array}{c}\text { G-2 } \\
\text { semi-fit } \\
\text { and fast }\end{array}$ & $\begin{array}{c}\mathrm{G}-4 \\
\text { semi-fit } \\
\text { and fast }\end{array}$ & $\begin{array}{l}\text { G-3 } \\
\text { fat yet } \\
\text { fast }\end{array}$ & $\begin{array}{c}\text { G-1 } \\
\text { fat and } \\
\text { slow }\end{array}$ & $\begin{array}{c}\text { G-5 } \\
\text { semi-fat } \\
\text { and slow }\end{array}$ \\
\hline $\begin{array}{l}\text { Number of } \\
\text { banks in cluster }\end{array}$ & 92 & 69 & 16 & 7 & 33 & 70 \\
\hline $\begin{array}{l}\% \text { of very fast } \\
\text { banks }\end{array}$ & $100 \%$ & $68.2 \%$ & $62.5 \%$ & $71.4 \%$ & $15.2 \%$ & $35.7 \%$ \\
\hline $\begin{array}{l}\% \text { of moderately } \\
\text { fast banks }\end{array}$ & - & $30.4 \%$ & $37.5 \%$ & - & $54.5 \%$ & $48.6 \%$ \\
\hline$\%$ of slow banks & - & $1.4 \%$ & - & $28.6 \%$ & $30.3 \%$ & $15.7 \%$ \\
\hline $\begin{array}{lll}\text { NPL to } & \text { Gross } \\
\text { loan } & & \text { (mean } \\
\text { value) } & & \\
\end{array}$ & $6.97 \%$ & $5.75 \% * * *$ & $3.19 \% * * *$ & $6.37 \%$ & $20.02 \% * * *$ & $8.07 \% * * *$ \\
\hline $\begin{array}{l}\text { ROE } \quad \text { (mean } \\
\text { value) }\end{array}$ & $7.37 \%$ & $9.64 \% * * *$ & $6.07 \% * * *$ & $0.35 \% * * *$ & $5.22 \% * * *$ & $5.6 \% * * *$ \\
\hline $\begin{array}{ll}\text { Total } & \text { capital } \\
\text { ratio } & \text { (mean } \\
\text { value) } & \end{array}$ & $20.78 \%$ & $18.06 \%$ & $24.11 \%$ & $17.08 \%$ & $24.23 \%$ & $19.38 \%$ \\
\hline $\begin{array}{l}\% \text { in Southern } \\
\text { regions }\end{array}$ & $12 \%$ & $7.25 \%$ & $0 \%$ & $0 \%$ & $72.7 \%$ & $15.7 \%$ \\
\hline $\begin{array}{l}\% \text { of specialized } \\
\text { banks }\end{array}$ & $2 \%$ & $2.89 \%$ & $0 \%$ & $42.9 \%$ & $12.1 \%$ & $4.3 \%$ \\
\hline $\begin{array}{l}\% \text { of thinking } \\
\text { heads }\end{array}$ & $88 \%$ & $76 \% * * *$ & $87 \%$ & $57.1 \% * *$ & $69.7 \% * * *$ & $81.4 \% *$ \\
\hline $\begin{array}{ll}\% & \text { of } \\
\text { cooperatives } & \end{array}$ & $65 \%$ & $62 \%$ & $56 \%$ & $14.3 \% * * *$ & $48.5 \% * *$ & $54.3 \% *$ \\
\hline $\begin{array}{l}\text { Net interest } \\
\text { margin }\end{array}$ & 3.65 & 3.60 & $3.44 * * *$ & 2.90 & 3.53 & $3.50 * * *$ \\
\hline $\begin{array}{l}\text { Loans /Number } \\
\text { of employees }\end{array}$ & 2,074 & $2,282 * *$ & 2,008 & 3,859 & 2,341 & 2,216 \\
\hline $\begin{array}{l}\text { Loans/Total } \\
\text { Assets }\end{array}$ & 66.93 & 68.43 & 68.24 & 72.14 & $53.46 * * *$ & $64.03 *$ \\
\hline $\begin{array}{l}\text { Equity/Total } \\
\text { Assets }\end{array}$ & 15.30 & $12.91 * * *$ & 14.68 & 29.20 & $13.26^{* *}$ & $13.47 * * *$ \\
\hline
\end{tabular}




\section{Table 7 A strategic map}

Banks in clusters are allocated in the $3 \times 3$ matrix according to their loan growth and their ability to grow thanks to "transitory factors" and to "structural factors". The "transitory hypothesis" states that large banks are facing (transitory) organizational problems and left room to small banks growth; the "structural factors hypothesis" states that. small banks can lever on their own specificities, combined with an ability to control risk and profitability.

\begin{tabular}{|c|c|c|c|}
\hline \multirow{2}{*}{\multicolumn{2}{|c|}{ Growth }} & \multicolumn{3}{|c|}{$\begin{array}{c}\text { Driven by transitory factors } \\
\text { (e.g. transitory large banks organizational problems) }\end{array}$} \\
\cline { 2 - 5 } & Yes & $\begin{array}{c}\text { Partially } \\
\text { (moderate } \\
\text { (fast growth) }\end{array}$ & No \\
(slow growth)
\end{tabular}




\section{Graph 1 Classification Tree.}

The dependent variable is a dummy variable that takes the value 1 if a bank's loan growth is greater than the sample median, and zero otherwise. Independent variables are NPL/Gross Loans and ROE. Overall classification ability is equal to $70 \%$.

Legenda:

Miglioramento $=$ Improvement

Nodo $=$ Node

Categoria $=$ Category

Totale $=$ Total

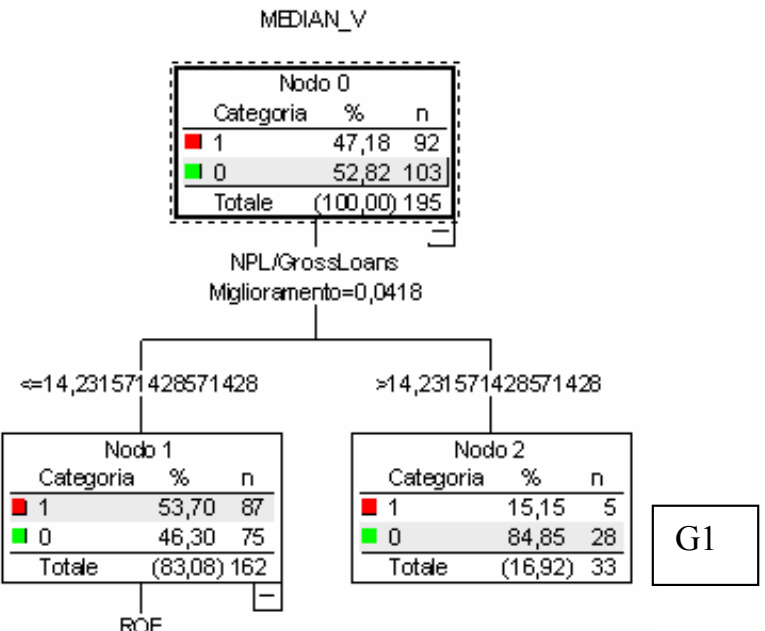

Migioramento $=0,0256$
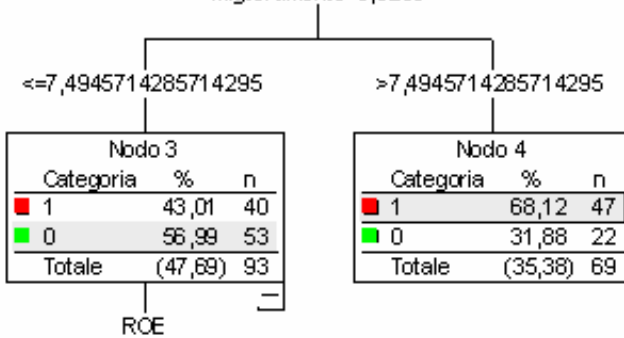

Miglioramerto $=0,0063$

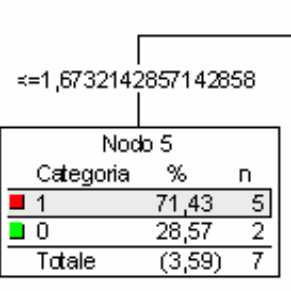

$=1,6732142857142858$

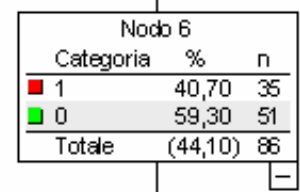

NPL/GrossLoans

Migioramento $=0,0096$

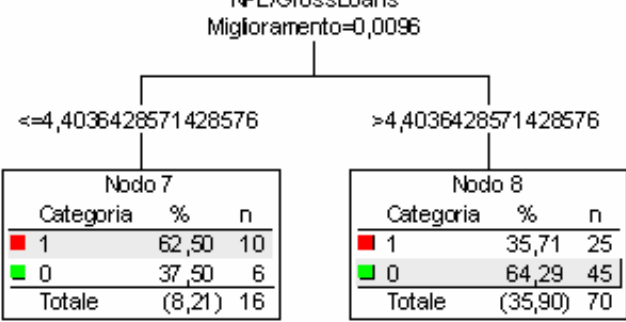

